\title{
Training Chilean primary health care professionals in nutrition for noncommunicable disease prevention
}

\author{
Ingrid Keller ${ }^{1}$ and Branka Legetic ${ }^{2}$
}

Suggested citation

Keller I, Legetic B. Training Chilean primary health care professionals in nutrition for noncommunicable disease prevention. Rev Panam Salud Publica. 2004;16(4):242-9.

ABSTRACT Objectives. To assess three related issues: (1) the need for training in nutrition and prevention of noncommunicable diseases (NCDs) as perceived by primary health care (PHC) personnel in Chile, (2) those health workers' preferred sources of training to learn about that subject, and (3) reactions to some materials that were later developed to help meet the needs that were identified.

Methods. In the summer of 2001 a questionnaire survey was used with PHC staff members in 3 of Chile's 13 regions in order to evaluate their perceived need for training in nutrition and NCD prevention as well as their preferred sources of continuing education. As a follow-up to the 2001 survey, in 2002, information material was prepared on using diet and physical activity to prevent NCDs. The information package was introduced through a series of workshops in all the regions of Chile. An evaluation in 2003 assessed the reactions to the new material.

Results. Four hundred thirty-one valid questionnaires from the 2001 survey were analyzed. The participants reported a strong need for further education in the area of nutrition for NCD prevention. The perceived need for further training was highest among nursing aides, and it was lowest among nutritionists. Most of the health personnel reported that patients often asked them about dietary issues, most frequently how to lose weight and how to follow a healthy diet. The sources of continuing education that the health workers had used most frequently were professional journals, information from the Ministry of Health, and courses. In comparison to the university-trained health professionals, the non-university-trained nursing aides differed significantly in their perceived need for more training, as well as the sources that they had used for continuing education ( $\mathrm{P}<0.05$ for both). The evaluation in 2003 to assess the reactions to the new information material found a generally favorable response to the package.

Conclusions. The Chilean PHC personnel perceived a strong need for training in nutrition as related to NCD prevention. In response, various activities are now being carried out, with goals that include enhancing the knowledge of PHC workers about possibilities for NCD prevention, encouraging a team approach to prevention, and offering more community-oriented services.

Key words Education, professional; health personnel; nutrition; chronic disease; health promotion; Chile.

1 World Health Organization, Noncommunicable Disease Prevention and Health Promotion, Geneva, Switzerland. Send correspondence to: Ingrid Keller, Noncommunicable Disease Prevention and
Health Promotion, World Health Organization, 20 Avenue Appia, CH-1211 Geneva 27, Switzerland; telephone: +41-22-791 3448; fax: +41-22-791 1581; e-mail: Kelleri@who.int.
2 Pan American Health Organization/World Health Organization Representation in Chile, Santiago de Chile, Chile. 
In recent decades the Chilean public health care system has been very successful in using national programs to improve maternal and child health and to reduce infectious disease prevalence. Consequently, the epidemiological profile of the country has changed. For example, the percentage of deaths attributable to noncommunicable diseases (NCDs) and accidents increased from $53.7 \%$ in 1970 to $75.1 \%$ in 1995 (1).

Standard measurements carried out nationally among children entering school (6 years of age) and among pregnant women found a steep rise in obesity (making comparisons using standard weight tables) in both these groups between 1987 and 1999. Obesity climbed from $6.5 \%$ to $14.0 \%$ among 6-year-olds, and from $13.0 \%$ to $32.0 \%$ among pregnant women (2). A survey of a representative sample of the adult population (25-64 years) of the city of Valparaiso found that there was an overall prevalence of $19.7 \%$ for obesity (body mass index $\geq 30$ ), with it being $23.0 \%$ among women and $15.7 \%$ among men (3).

The risk factors for NCDs have not been evaluated systematically in Chile. However, the first nationally representative survey on quality of life among adults was carried out in 2000. That survey found that $40 \%$ of the adults were daily smokers and that $91 \%$ were physically inactive. Some $47 \%$ reported eating fruits and vegetables every day, but only $35 \%$ said they consumed milk products daily (4).

The personnel in the Chilean national health care system have not been trained to cope with these challenges. Chile has a mixed public/private health care system. The public system provides health care to over $65 \%$ of the population. Chile has 13 geographic and administrative regions as well as 28 "Health Services." In each region there are one or more Health Services. These Health Services coordinate the public health care system at the primary, secondary, and tertiary levels.

The responsibility, infrastructure, and personnel to deliver primary health care (PHC) is at the municipal level. Chile has 345 primary health care centers, which provide health promotion, protection, and treatment services to designated populations. Located in both urban and rural areas, the centers are staffed by physicians, nurses, nutritionists, midwives, and nursing aides.

In the area of nutrition the PHC services are predominantly focused on evaluating the nutritional status of young children, pregnant women, and older persons as well as preventing undernutrition among these vulnerable groups by distributing supplementary foods to them. Nevertheless, new challenges are appearing in Chile, with a rise in excess energy intake and the resulting overweight and other health problems that are related to an unbalanced diet. Further, prevention and treatment of overweight and other NCD-related nutrition issues are only partially covered in the education that nutritionists and other professionals in Chile receive during their degree studies as well as during later continuing education.

Considering the magnitude of NCDs in Chile, it is vital that not only the nutritionists but also all the other health personnel on the PHC teams assume an active role in their contacts with patients and the public so as to encourage lifestyle changes, especially ones related to diet. Evidence in the scientific literature indicates that health personnel need additional training in order to be able to provide appropriate advice on a healthy diet $(5,6)$. The Canadian Heart Health Initiative has shown that interdisciplinary training for health professionals resulted in long-term interdisciplinary cooperation that benefited the public and patients by providing them with better information and advice (7). Having all health personnel work together as a team to deal with nutrition as a crosscutting issue is also promoted in a position paper by the American Dietetic Association (8). Recent intervention trials in Finland and in the United States of America have shown that non-insulin-dependent diabetes mellitus could be prevented in high-risk patients treated with intensive lifestyle interventions by a multidisciplinary team $(9,10)$.
As a response to the increasing risk of NCDs in Chile, a National Plan for Health Promotion was agreed upon in 1997 (11). Among its priority areas are the promotion of a healthy diet and the lowering of the prevalence of obesity in the general population, in particular among school children and pregnant women. Further, in 1996 Chile joined the CARMEN initiative (Conjunto de Acciones para la Reducción Multifactorial de Enfermedades No Transmisibles, or Set of Actions for the Multifactorial Reduction of Noncommunicable Diseases) of the Pan American Health Organization (PAHO). The CARMEN initiative is modeled after the Canadian/European experience of the Countrywide Integrated Noncommunicable Disease Intervention (CINDI).

The national CARMEN-Chile initiative encourages an integrated approach to health promotion, prevention, early detection, and cure. The initiative is based on interventions within the health care system and in the community that are planned and performed with the aim of slowing and reversing leading risk factors such as obesity, sedentary lifestyle, smoking, hypertension, hypercholesterolemia, and glucose intolerance. The CARMEN initiative is carried out in 3 of the 13 regions of Chile, with demonstration areas in 7 of the 28 Health Services.

In its national health goals for the decade of 2000 to 2010, Chile affirmed the need to change the trends in the health problems that are the leading causes of premature mortality and disability in the country (12). Since the CARMEN-Chile initiative has a strategy to combat the main risk factors and leading NCDs, it was decided to explore, within the initiative, the need that PHC personnel have for training in the area of NCD prevention and health promotion, with a particular focus on healthy lifestyles, including healthy diet and physical activity. A survey among PHC workers was therefore conducted in the three regions participating in the CARMEN initiative, with the following objectives: (1) to assess the level of training in NCD prevention, particularly the 
nutrition component, that had been received during university or vocational education; (2) to obtain information about the sources of professional information and the preferred sources of continuing education; and (3) to develop for the PHC workers an educational strategy in NCD prevention and health promotion.

\section{METHODS}

The survey for our study was conducted among a sample of PHC personnel who were working in the CARMEN demonstration areas in the country. All the seven Health Services participating in the CARMEN initiative participated in the survey: (1) five Health Services in Region VIII, (2) the Valparaiso Health Service, and (3) the Southeast Metropolitan Health Service of the city of Santiago de Chile. These seven Health Services had a total of 129 PHC centers, with 1136 staff members: 246 physicians, 220 nurses, 104 nutritionists, 158 midwives, 90 social workers, and 318 nursing aides. For our study we sent survey questionnaires to only the 72 PHC centers that were actively participating in the CARMENChile initiative. Those 72 centers had a total of 521 PHC workers.

The survey instrument was a selfadministered questionnaire, composed of 51 items, especially developed for this survey. It included questions on all education received (both degree studies and later continuing education), distinguishing between universitytrained PHC workers and PHC workers who did not receive their training in a university program. There were also questions on habits and preferences regarding continuing education, including the customary sources of information, preferred sources of information, and plans to participate in continuing education. The questionnaire also asked which nutrition-related topics patients asked about the most. The last part of the questionnaire asked the PHC workers about their own personal dietary habits, tobacco use, and physical activity practices. The assessment of their dietary habits was based on the seven nutritional guidelines of the Chilean Ministry of Health (13). The questionnaire asked about the frequency of intake (per day or per week) of various foods, based on the recommendations given in the guidelines. The questions on tobacco use were based on the CINDI Finbalt Health Monitor questionnaire (14). The Spanish-language version of the International Physical Activity Questionnaire (15) was used to assess physical activity. We pretested the questionnaire in a PHC center in Santiago de Chile that did not participate in the subsequent survey. The results of the questions on personal lifestyle are reported elsewhere (16).

The questionnaire was distributed to the 72 PHC centers via the seven Health Services. The completed questionnaires were sent through the Pan American Health Organization/ World Health Organization (WHO) office in Santiago de Chile to WHO Headquarters in Geneva for coding and data analysis. All the questionnaires were coded on the MS Excel 1997 software program (Microsoft Corporation, Redmond, Washington, United States) and subsequently analyzed using that same program. Statistical tests were performed using the SPSS software program (SPSS Inc., Chicago, Illinois, United States). Due to the scale of the data tested (mostly nominal), and taking into consideration that the data were not normally distributed and did not show homogeneity in their variances, KruskalWallis tests and subsequently MannWhitney tests were performed.

As a follow-up to this survey, in the spring and summer of 2002 a package of information material on health promotion and NCD prevention through diet and physical activity was prepared jointly by the Chilean National Institute for Food Technology and $\mathrm{Nu}$ trition, the Ministry of Health of Chile, WHO Headquarters, and the PAHO/ WHO Representation in Chile. The material took into consideration the preferences for the sources of continuing education that the PHC workers had indicated in the surveys. The content of the package is summarized in
Table 1. It includes overhead-projector transparencies that can be used by health personnel who give educational talks to patients and the general public. The material is also provided on a CD-ROM for easy reproduction at the local level.

The information package was introduced first to the 7 Health Services that had CARMEN initiative demonstration areas, and then to the 21 other Health Services in the country. Interdisciplinary workshops were put on by experts from the National Institute for Food Technology and Nutrition and the Ministry of Health in the summer of 2002 to promote the package's use by the multidisciplinary PHC teams as well as teamwork in general in the areas of health promotion and NCD prevention. In the summer of 2003 an evaluation of the educational package was carried out in all 28 of the Health Services in Chile.

\section{RESULTS}

Of the 521 questionnaires distributed in 2001, 433 of them were received (overall response rate $83 \%$ ). Of these 433, 2 had to be discarded due to incomplete data. The remaining 431 questionnaires came from the following PHC staff members: 85 physicians, 88 nurses, 51 nutritionists, 50 midwives, 38 social workers, 106 nursing aides, and 13 others (dentists, physical therapists, etc.). Those 13 "others" were omitted in the subsequent analysis. With the exception of nursing aides, all the personnel mentioned have to have a university degree that requires five to seven years of study. A nursing aide degree can be obtained through participation in a course from a vocational training school. The course must last a minimum of 1200 hours, including practical and theoretical training.

According to the questionnaire responses, $58 \%$ of the physicians surveyed were men, whereas more than $90 \%$ of all the other health workers were women. Physicians were on average younger than the other PHC personnel (Table 2). 
TABLE 1. Index of the informational material produced for primary health care workers, Chile, 2002

\begin{tabular}{|c|c|}
\hline Section & Contents \\
\hline Introduction & Introduction \\
\hline $\begin{array}{l}\text { Nutrition education and dietary guidelines for the } \\
\text { prevention of noncommunicable diseases }\end{array}$ & $\begin{array}{l}\text { Educational interventions based on food-based dietary guidelines and how to include all sectors } \\
\text { concerned }\end{array}$ \\
\hline Dietary guidelines and nutritional requirements & $\begin{array}{l}\text { Presentation and explanation of the Chilean dietary guidelines, including a plan for a healthy diet, with } \\
\text { examples for dietary intake across the life course }\end{array}$ \\
\hline Food labeling & Practical examples and illustrations that can be shared with the public and patients \\
\hline Noncommunicable diseases & $\begin{array}{l}\text { For each disease, risk factors are highlighted and preventive measures through diet and physical } \\
\text { activity are discussed } \\
\text { - Cardiovascular diseases } \\
\text { - Cancer } \\
\text { - Diabetes } \\
\text { - Osteoporosis } \\
\text { - Obesity } \\
\text { - Prevention of overweight and obesity } \\
\text { - Dietary management of the overweight and obese adult (a practical guide with background text, an } \\
\text { algorithm for treating overweight patients, and various questionnaires for assessing the lifestyle of } \\
\text { patients) }\end{array}$ \\
\hline "Physical activity" & The official Chilean picture-based guide for an active life \\
\hline "Your guide for a future without tobacco" & (from the InterAmerican Heart Foundation) \\
\hline Annexes & $\begin{array}{l}\text { - Guide on how to create an inventory of community-based activities promoting healthy lifestyles } \\
\text { - Suggested readings and Internet sources } \\
\text { - Table with total fat content, fatty acids, and cholesterol of selected foods }\end{array}$ \\
\hline Complementary materials: & $\begin{array}{l}\text { - Educational brochures for patients from the Cardiovascular Health Program of the Chilean Ministry of } \\
\text { Health } \\
\text { - Physical activity posters from World Health Day } 2002\end{array}$ \\
\hline
\end{tabular}

TABLE 2. Characteristics of the primary health care (PHC) workers surveyed, Chile, 2001

\begin{tabular}{|c|c|c|c|c|c|c|}
\hline & Physicians & Nurses & Nutritionists & Midwives & $\begin{array}{c}\text { Social } \\
\text { workers }\end{array}$ & $\begin{array}{c}\text { Nursing } \\
\text { aides }\end{array}$ \\
\hline Number of participants & 85 & 88 & 51 & 50 & 38 & 106 \\
\hline Years worked in PHC (mean) & 5 & 11 & 12 & 11 & 8 & 12 \\
\hline Mean age (yr) & 34 & 42 & 41 & 39 & 39 & 39 \\
\hline Women (\%) & 42 & 95 & 99 & 99 & 94 & 94 \\
\hline Married (\%) & 55 & 66 & 62 & 62 & 49 & 57 \\
\hline
\end{tabular}

Overall, $44 \%$ of the survey respondents said that nutrition of adults was included in their degree studies $(21 \%$ of the nursing aides reported that); $37 \%$ overall said that nutrition and its role in the prevention of NCDs was included $(20 \%$ of the nursing aides reported that). The health workers were asked to rate their own need for further training in nutrition and NCD prevention, using a scale from 1 (no need) to 10 (high need) (Table 3 ). The mean score overall was 7.9.

Figure 1 shows the relationship that training received in adult nutrition and in nutrition and NCD prevention had with the perceived need for more education. Three groups of the health workers who had received less trainingmidwives, social workers, and nursing aides-perceived a significantly greater need $(P<0.05)$ for being trained further. In contrast, physicians reported feeling the need for more training even though they had received relatively more training. The perceived need for further training was significantly higher in the nursing aides than it was in the other, university-trained health workers $(P<$ $0.05)$. These patterns were true for training in adult nutrition, training in nutrition and NCDs, and training in both of those fields.

After completion of their degree studies, about $34 \%$ of the health workers had participated in a course on nutrition and NCD prevention. The highest percentage of participation was among nutritionists (86\%), and the lowest was among midwives (21\%) and physicians (17\%).

About $61 \%$ of the participants said that patients frequently asked about 
TABLE 3. Training received during degree studies by primary health care workers, and their current perceived need for more training, Chile, 2001

\begin{tabular}{lcccccc}
\hline & Physicians & Nurses & Nutritionists & Midwives & $\begin{array}{c}\text { Social } \\
\text { workers }\end{array}$ & $\begin{array}{c}\text { Nursing } \\
\text { aides }\end{array}$ \\
\hline $\begin{array}{l}\text { Earlier training in adult nutrition } \\
\begin{array}{l}\text { Earlier training in nutrition and } \\
\text { prevention of noncommunicable } \\
\text { diseases }\end{array}\end{array}$ & $51 \%$ & $69 \%$ & $90 \%$ & $28 \%$ & $9 \%$ & $22 \%$ \\
$\begin{array}{l}\text { Perceived need for more training } \\
(\text { mean) }\end{array}$ & $44 \%$ & $52 \%$ & $72 \%$ & $29 \%$ & $11 \%$ & $21 \%$ \\
\hline
\end{tabular}

a The perceived need for more training was rated on a scale from 1 (low) to 10 (high).

nutrition issues. Nearly all the nutritionists (96\%) reported being asked frequently about nutrition; $70 \%$ of the physicians and $78 \%$ of the nurses said they were frequently asked about nutrition. Among social workers about $35 \%$ reported being asked about nutrition. The topics that the PHC personnel said that patients raised most frequently were how to lose weight (mentioned by $62 \%$ of PHC workers) and how to follow a healthy diet $(55 \%$ of PHC workers) (Table 4).

In Chile there are no formal requirements for continuing education that are related to licensing, but there is a "culture" of continuing education within the health profession community: More education can make it possible to obtain a higher level of responsibility within the profession or to change one's profession.
According to the results of our 2001 survey, the sources of continuing education most frequently used by the various health professionals were professional journals; information, materials, and guidelines from the national Ministry of Health; and attending, in person, continuing education courses given by universities, professional associations, and other health organizations in the country (Table 5).

In terms of the sources of continuing education that they had used, the nursing aides in our study differed significantly from the other, universitytrained health workers $(P<0.05)$. The nursing aides were less involved in continuing education. They reported much less frequent use of the various sources of further education, and when they did report further education, the main resource was colleagues.

With respect to the methods that the PHC personnel in our study would prefer for continuing education, written materials (for example, ones

FIGURE 1. Training in adult nutrition and in nutrition and noncommunicable disease (NCD) prevention received during degree studies, in comparison to perceived need for continuing training in this field, Chile, 2001a

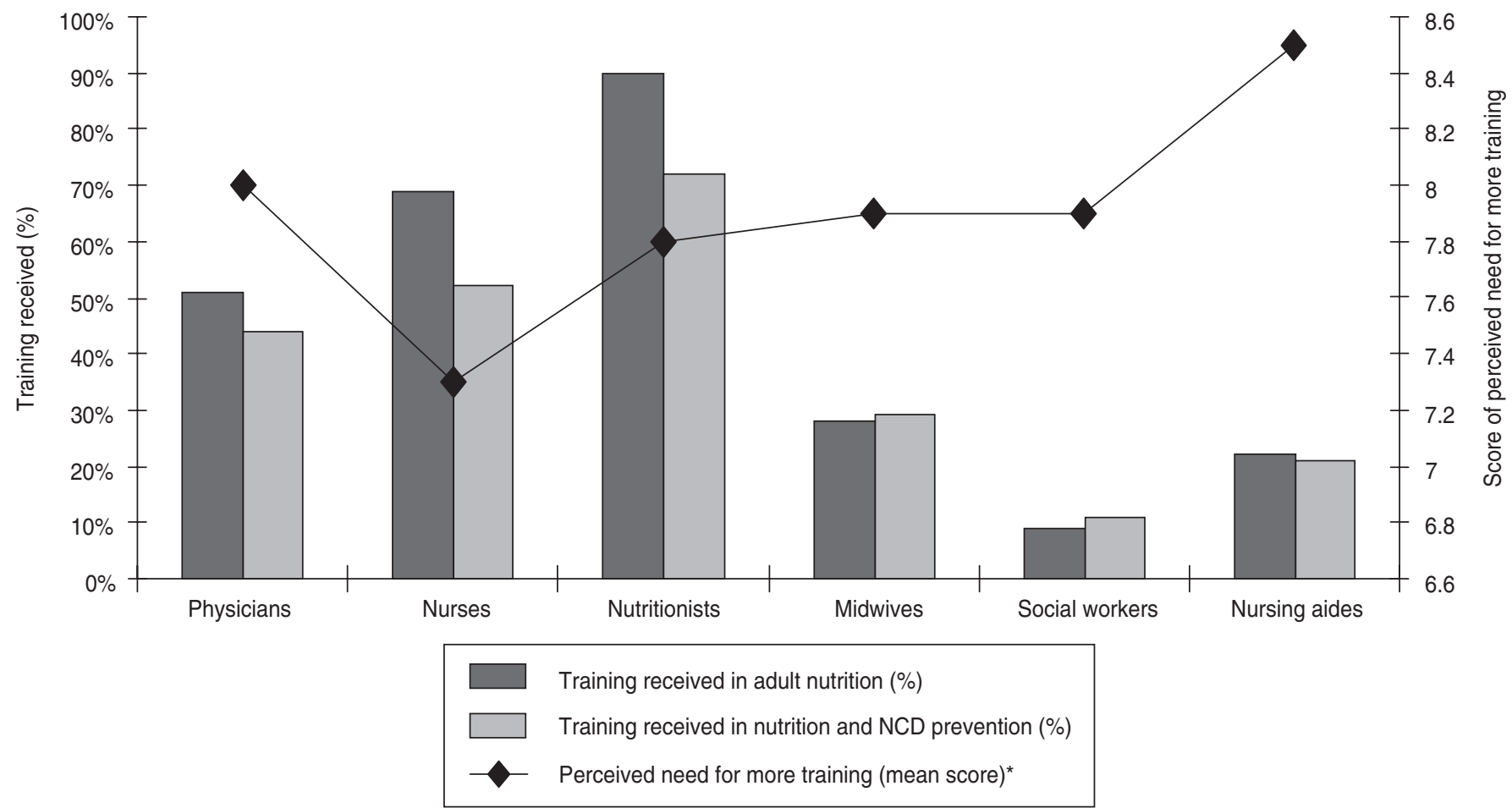

a The perceived need for more training is rated on a scale from 1 (low) to 10 (high). 
TABLE 4. Nutrition-related topics that primary health care (PHC) workers said that patients asked about most often, Chile, 2001

\begin{tabular}{lc}
\hline \multicolumn{1}{c}{ Topic about which patients ask } & $\begin{array}{c}\text { Percent of PHC workers } \\
\text { reporting that patients } \\
\text { frequently ask about the topic }\end{array}$ \\
\hline How to lose weight & 62 \\
Healthy diet & 55 \\
Nutrition of older persons & 43 \\
Healthy foods & 38 \\
Nutrition during pregnancy & 37 \\
Adult nutrition & 36 \\
Child nutrition & 35 \\
Nutrition and prevention of noncommunicable diseases & 24 \\
\hline
\end{tabular}

TABLE 5. Sources for continuing education that had been used by primary health care workers (\%), Chile, 2001

\begin{tabular}{|c|c|c|c|c|c|c|}
\hline & Physicians & Nurses & Nutritionists & Midwives & $\begin{array}{c}\text { Social } \\
\text { workers }\end{array}$ & $\begin{array}{l}\text { Nursing } \\
\text { aides }^{a}\end{array}$ \\
\hline Professional journal & 63 & 46 & 51 & 61 & 17 & 16 \\
\hline Colleagues & 25 & 45 & 51 & 17 & 51 & 34 \\
\hline Professional association & 7 & 7 & 16 & 7 & 0 & 2 \\
\hline National Ministry of Health & 35 & 40 & 67 & 54 & 34 & 8 \\
\hline Health Service & 17 & 36 & 31 & 41 & 31 & 16 \\
\hline $\begin{array}{l}\text { Courses (distance or taken } \\
\text { in person) }\end{array}$ & 37 & 37 & 53 & 28 & 31 & 16 \\
\hline
\end{tabular}

a For nursing aides in comparison to all other primary health care workers combined there is a statistically significant difference in the sources of continuing education used $(P<0.05)$.

TABLE 6. Media that primary health care workers (\%) would prefer to use for continuing education, Chile, 2001

\begin{tabular}{|c|c|c|c|c|c|c|}
\hline & Physicians & Nurses & Nutritionists & Midwives & $\begin{array}{c}\text { Social } \\
\text { workers }\end{array}$ & $\begin{array}{l}\text { Nursing } \\
\text { aides }\end{array}$ \\
\hline Written media & 50 & 42 & 54 & 57 & 47 & 38 \\
\hline Electronic media & 51 & 43 & 40 & 20 & 37 & 11 \\
\hline Distance course & 14 & 27 & 44 & 18 & 16 & 10 \\
\hline Course taken in person & 45 & 36 & 36 & 55 & 45 & 41 \\
\hline
\end{tabular}

received from the Ministry of Health) and courses taken in person were the ones cited most frequently (Table 6). Physicians and nurses indicated their first preference as being interactive courses using electronic media (e.g., on CD-ROM or via the Internet).

In the summer of 2003 a follow-up evaluation of the educational kit was carried out among all 28 of the Health Services in Chile. The study was performed by the National Institute for about 1800 PHC personnel. Of these workers, 26\% were nurses, 20\% medical doctors, $20 \%$ nutritionists, $12 \%$ nursing aides, and the remainder midwives, social workers, etc. In addition, more than 450 local activities, such as presentations on health, diet, and physical activity in schools and the workplace, had been held to educate the general public.

\section{DISCUSSION}

The key finding of our study is that Chilean primary health care workers report a strong need for continuing education in the area of nutrition as a risk factor for chronic diseases. With the exception of physicians, we found a statistically significant difference in the reported need for more training between those PHC personnel who report having received more training vs. those who reported having received less training. There is also an important, significant difference between university-trained PHC staff overall and non-university-trained nursing aides, with the nursing aides reporting less involvement in continuing education, less nutrition training, and a higher need for additional training.

Data from the United Kingdom showed that there was a strong interest among practice nurses and general practitioners in attending a course on healthy nutrition (6). Further, 95\% of the practice nurses reported they wished they had had training in nutrition during their medical training, and $80 \%$ of the general practitioners also said that.

The scientific literature supports the importance that PHC personnel place on a high level of knowledge of the role of nutrition in NCD prevention. PHC professionals are the first and primary contact that many patients have within the health care system, and the advice that these workers provide is important to the decisions that patients make (17, 18). For example, a lack of professional training may be a hindrance in advising women of childbearing age on the risks of obesity and how to lose weight (19). Data from South Africa show that in- 
adequate training for health care staff members contributes to unsatisfactory management of diabetic and hypertensive patients (20).

Our data have some limitations. The data are in part the result of a study done in 2001 among PHC workers in the CARMEN-Chile initiative demonstration areas and therefore may not be representative of all the PHC workers in the country. The PHC personnel in the CARMEN areas might be more motivated to participate in such a survey, and they also might be more aware of NCD prevention and health promotion practices.

The university-trained professionals in our study frequently reported that when courses on nutrition and NCDs were included in their overall training (either degree studies or continuing education), the focus was more on dietary management of, for example, diabetic or hypertensive patients, and less on primary prevention through a healthy diet. The origins of this training lie in the epidemiological profile of Chile in the 1960s, when the country's primary health care system was organized and when mortality was due mainly to infectious diseases and malnutrition. Given Chile's changing epidemiological profile, this training model is outdated. Further, this acute care model is not based on a team approach or on ongoing contact between PHC workers and patients. Generally, PHC professionals are also not being trained within their degree programs to assume a population-based ap- proach to health care. Continuing education activities held within the CARMEN initiative aim to narrow this gap by highlighting the importance of prevention and of a team approach to managing patients. However, universities in Chile should also consider adaptations in their curricula for all health professionals.

The knowledge base on nutrition and NCDs has grown rapidly in recent years. It is important that this expanded knowledge filter down to the PHC level. For example, the preventive benefits of high fruit and vegetable consumption as well as of low salt consumption $(21,22)$ should be communicated thoroughly to the PHC team. Our data show that patients frequently ask about healthy eating and how to lose weight; however, they ask less about nutrition in relation to NCDs. A reason may be that they are not aware of the link, which points to the need for PHC staff to be well informed and to pass this knowledge on to their patients.

At the PHC level, particular emphasis must be placed on a team approach rather than a physician-based approach. For example, in the late 1980s Finland began implementing a "population responsibility" principle in health centers, with specially trained primary health care nurses working together with physicians and dietitians (23). Finnish researchers recently studied having a trained nurse offer intensified diet counseling to hypertensive patients (24). That counseling resulted in dietary changes among the patients that were beneficial for the long-term treatment of their hypertension. A PHC team approach is also favored in Hong Kong for enhancing the effectiveness of health services (25). Including PHC professionals in community-based activities to promote a healthy diet in order to prevent NCDs is indispensable, as has been demonstrated in Finland's North Karelia Project (26).

In conclusion, our survey has shown that Chilean PHC workers perceive the need for more training in the areas of adult nutrition and of nutrition and NCD prevention. Activities carried out through the CARMEN program in Chile are providing this training, with the aims of enhancing the knowledge that PHC professionals have about possibilities for NCD prevention, encouraging a team approach to prevention, and offering more communityoriented services.

Acknowledgements. The authors would like to thank María Cristina Escobar Fritsche and Xenia Benavides, from the Chilean Ministry of Health, and Isabel Zacharías and Sonia Olivares, from the Instituto Nacional de Tecnología de Alimentos y Nutrición in Chile, for their dedication to the project and the leading role they played in preparing and disseminating the information material. We also thank Pekka Puska and Sylvia Robles for comments on earlier versions of this paper.

\section{REFERENCES}

1. Vio F, Albala C. Nutrition policy in the Chilean transition. Public Health Nutr. 2000; 3(1):49-55.

2. Consejo Nacional para la Promoción de la Salud VIDA CHILE. Cuenta pública 2001. Santiago, Chile: Ministerio de Salud; 2002.

3. Jadue L, Vega J, Escobar MC, Delgado I, Garrido $C$, Lastra $P$, et al. Factores de riesgo para las enfermedades no transmisibles: metodología y resultados globales de la encuesta de base del programa CARMEN (Conjunto de Acciones para la Reducción Multifactorial de las Enfermedades no Transmisibles). Rev Med Chil. 1999;127:1004-13.
4. Chile, Ministerio de Salud, Departamento de Epidemiología. Encuesta Calidad de Vida 2000. Santiago, Chile: Ministerio de Salud; 2001.

5. Cadman L, Wiles R. Nutrition advice in primary care: evaluation of practice nurse nutrition training programmes. J Hum Nutr Diet. 1996;(9):147-56

6. Hopper D, Barker ME. Dietary advice, nutritional knowledge and attitudes towards nutrition in primary health care. J Hum Nutr Diet. 1995;(8):279-86.

7. Health Canada. Canadian Heart Health Initiative: process evaluation of the demonstration phase. Ottawa: Conference of Principal Investigators of Heart Health; 2002.

8. American Dietetic Association. Position of the American Dietetic Association: nutrition education of health professionals. J Am Diet Assoc. 1991;91(5):611-3.

9. Tuomilehto J, Lindström J, Eriksson J, Valle T, Hämäläinen $\mathrm{H}$, Ilanne-Parikka $\mathrm{P}$, et al. Prevention of type 2 diabetes mellitus by changes in lifestyle among subjects with impaired glucose tolerance. N Engl J Med. 2001;344(18): 1343-50.

10. United States of America, National Institute of Diabetes and Digestive and Kidney Diseases, 
Diabetes Prevention Program. Diet and exercise dramatically delay type 2 diabetes: diabetes medication metformin also effective [press release], 8 August 2001. Available from: http:/ / www.niddk.nih.gov/welcome / releases/8_8_01.htm [Internet site]. Accessed 29 January 2003.

11. Chile, Ministerio de Salud, División de Atención Primaria. Promoción de la salud para Chile. Plan Nacional de Promoción de la Salud. Santiago, Chile: Ministerio de Salud; 1999

12. Chile, Ministerio de Salud. Los objetivos sanitarios para la década 2000-2010. Available from: http://epi.minsal.cl [Internet site]. Accessed 2 August 2004.

13. Castillo C, Uauy R, Atalah E. Guías alimentarios para la población chilena del Instituto $\mathrm{Na}$ cional de Tecnología de Alimentos y Nutrición. Santiago, Chile: Diario La Nación; 1997.

14. World Health Organization/Regional Office for Europe, CINDI project. Methodology for a health behaviour survey; CINDI Health Monitor Questionnaire. Available from: http:// www.who.dk/Document/Chr/Cinheamon quest.pdf [Internet site]. Accessed 21 December 2003.
15. The International Physical Activity Questionnaire (IPAQ). Available from: http://www. ipaq.ki.se/[Internet site]. Accessed 21 December 2003.

16. Keller I, Legetic B, Escobar Fritsche MC. Estilo de vida del personal de atención primaria de salud en Chile. Rev Med Chil. Forthcoming 2004.

17. Frank E, Rothenberg R, Lewis C, Belodoff B. Correlates of physicians' prevention related practices. Arch Fam Med. 2000;9:359-67.

18. Rosso S, Battista RN, Segnan N, Williams JI, Suissa S, Ponti A. Determinants of preventive practices of general practitioners in Torino, Italy. Am J Prev Med. 1992;8(6):339-44.

19. Cogswell ME, Perry GS, Schieve LA, Dietz WH. Obesity in women of childbearing age: risks, prevention and treatment. Prim Care Update Ob/Gyns. 2001;8(3):89-105.

20. Kalk WJ, Veriawa Y, Osler C. A survey of hospital outpatient services for chronic diseases in Gauteng. S Afr Med J. 2000;90(1):57-61.

21. World Health Organization. World health report 2002. Geneva: WHO; 2002.

22. World Health Organization. Diet, nutrition and the prevention of chronic diseases. Report of a joint $\mathrm{WHO} / \mathrm{FAO}$ expert consulta- tion. Geneva: WHO; 2003. (WHO Technical Report Series 916).

23. Koponen P, Helio SL, Aro S. Finnish public health nurses' experience of primary health care based on the population responsibility principle. J Adv Nurs. 1997;26(1):41-8.

24. Korhonen M, Kastarinen M, Uusitupa M, Puska P, Nissinen A. The effect of intensified diet counselling on the diet of hypertensive subjects in primary health care: a 2-year open randomized controlled trial of lifestyle intervention against hypertension in Eastern Finland. Prev Med. 2003;36:8-16.

25 . Lee A. The need for integrated primary health care to enhance the effectiveness of health services. Asia Pac J Public Health. 2003;15(1): 62-7.

26. Puska P, Tuomilehto J, Nissinen A, Vartiainen E. The North Karelia Project. 20 year results and experiences. Helsinki: National Public Health Institute; 1995.

Manuscript received 18 June 2003. Manuscript accepted for publication 23 July 2004
RESUMEN

Adiestramiento de profesionales de atención primaria en Chile sobre la alimentación orientada a prevenir las enfermedades no transmisibles
Objetivos. Explorar tres cosas vinculadas entre sí: 1) cómo el personal de atención primaria de salud (APS) en Chile percibe la necesidad de adiestramiento sobre el papel de la alimentación en la prevención de las enfermedades no transmisibles (ENT), 2) cuáles son las fuentes de adiestramiento sobre el tema que estos profesionales prefieren, y 3) qué reacciones suscitaron algunos de los materiales que más tarde se elaboraron para satisfacer las necesidades identificadas.

Métodos. En el verano de 2001 se le administró un cuestionario por encuesta al personal de APS en tres de las 13 regiones de Chile con objeto de evaluar sus percepciones acerca de la necesidad de adiestramiento sobre el papel de la alimentación en la prevención de ENT, y acerca de sus fuentes preferidas de educación continuada. Como seguimiento a la encuesta de 2001, en 2002 se prepararon materiales informativos sobre cómo la alimentación y la actividad física pueden ayudar a prevenir las ENT. El paquete informativo se introdujo en una serie de talleres que se celebraron en todas las regiones de Chile. En 2003 se evaluaron las reacciones a los nuevos materiales suministrados.

Resultados. Se analizaron 431 cuestionarios válidos recogidos en la encuesta de 2001. Los participantes indicaron una gran necesidad de recibir más instrucción sobre el papel de la alimentación en la prevención de las ENT. Quienes más percibían esta necesidad eran los auxiliares de enfermería, y quienes menos la percibían eran los nutricionistas. La mayor parte del personal de salud indicó que los pacientes a menudo les hacían preguntas sobre cuestiones de alimentación, casi siempre cómo bajar de peso y consumir una dieta saludable. Las fuentes de educación continuada que los trabajadores de la salud habían usado con mayor frecuencia fueron las revistas para profesionales, la información provista por el Ministerio de Salud y los cursos académicos. Los profesionales con educación universitaria difirieron de los auxiliares de enfermería, que carecían de ella, en su percepción acerca de la necesidad de recibir más adiestramiento, así como en el tipo de fuentes de educación continuada empleadas, siendo significativa la diferencia en ambos casos $(P<0,05)$. La evaluación realizada en 2003 para ver las reacciones evocadas por el nuevo material informativo reveló una acogida favorable del paquete.

Conclusiones. El personal de APS de Chile percibió una gran necesidad de recibir más instrucción sobre el papel de la alimentación en la prevención de las ENT. Como resultado, actualmente se están llevando a cabo diversas actividades encaminadas a mejorar los conocimientos de los trabajadores de APS sobre las posibles formas de prevenir las ENT, a reforzar el trabajo en grupo para las actividades de prevención y a ofrecer un mayor número de servicios orientados hacia la comunidad. 